\title{
Vigilantes, Witches and Vampires: How Moral Populism Shapes Social Accountability in Northern Uganda
}

\author{
Tim Allen \\ Professor, London School of Economics, London, U K \\ t.allen@lse.ac.uk
}

\begin{abstract}
Strange murders have occurred in northern Uganda. Blood is said to have been removed from the victims, and there are tales about child sacrifice and terrifying witchcraft. An 'election' was organised to select the culprit, known as 'Mr Red', and vigilante mobs have destroyed his property. This article places these events in context, and shows how understandings of the spirit world, religion, and wealth accumulation relate to local notions about egregious acts. No conventional evidence has been found to show that the man accused is responsible for any crimes, but he has been imprisoned, and has had threats on his life. The case illustrates widespread phenomena, which are too often ignored, and draws attention to the ways in which local elites draw on strategies of moral populism to establish and maintain their public authority.
\end{abstract}

\section{Keywords}

witchcraft - vigilantes - vampires - local justice - northern Uganda

1 Support for this article was provided by The Justice and Security Research Programme, based at the London School of Economics and funded by DFID. Fieldwork was carried out by the author with invaluable assistance from Tonny Labol, Jackline Atingo, Dorothy Atim, and Joshua Allen. The author also grateful to Moses Adonga, Alex de Waal, Holly Porter, Rebecca Tapscott, Anna Macdonald and Sophie Hooge Seebach, all of who generously provided detailed comments.

(C) TIM ALLEN, 2015 | DOI 10.1163/15718115-02203004

This is an open access article distributed under the terms of the Creative Commons Attribution-

NonCommercial 4.o (CC-BY-NC 4.0) License. http://creativecommons.org/licenses/by-nc/4to9//26/2023 12:15:34PM 


\section{Introduction}

In August 2014, the town of Gulu in the Acholi region of northern Uganda was buzzing with stories about murders allegedly linked to the activities of someone called 'Mr Red'. Bodies had been found with a crack in the left side of their skull. There was also talk about strange holes in their necks, blood being sucked out and brains removed. Rumours were rife of child sacrifice and of satanic rites. Mr Red, it was alleged, had made alliances with witchdoctors who had used evil techniques to make him rich. A casting of votes in an election had been organised to confirm responsibility for the killings, and Christian activists, local councillors, Members of Parliament (MPs), other government offcials and even the police were involved in supporting popular justice responses. Violent actions were being condoned or actively promoted in explicitly moral terms, and there were further deaths in confused nocturnal clashes. This paper examines these events. It places them in context, and describes what happened next. It relates the case of Mr Red to other collective panics and to prevalent ideas about witchcraft, spirituality and public authority, which affect the everyday lives of Acholi people. In so doing, it draws attention to characteristics of local leadership, and in particular to the use of what might be called 'moral populism' in ways that set aside, or incorporate, formal systems. Moral populism here refers to an explicit linking of notions of good and bad with assertions by individuals that they articulate the will or the best interests of the people.

The Mr Red story takes place in a part of Uganda affected by the long war between the government of President Museveni and the Lord's Resistance Army (LRA) since the mid-1980s. That obviously gives it specificities. The power and resilience of the LRA was linked to Acholi ideas about the metaphysical capacities of its leader, Joseph Kony. Also the horrors of life in displacement camps and the terrifying acts of the LRA, including mutilations and abductions of children, are a very recent memory. Nevertheless, fear and jealously connected with the relative wealth of some individuals, the sudden deaths of others, and the suspicious or dangerous activities of migrants and other outsiders are far from unique. So is the absorbing of new ideas linked to international notions of modernity, or taken from films and news media into local idioms. As Luise White has shown in her study of conspiracy theories associated with vampire stories in colonial Africa, recent events in Gulu have a long history.2

2 L. White, Speaking with Vampires: Rumor and History in Colonial Africa (University of California Press, Berkeley, 200o). 
White is one of several scholars who have shown the value of taking everyday descriptions of extraordinary occurrences seriously. ${ }^{3}$ Witch-hunts, sorcery, possession by spirits and tales of blood-suckers, zombies and shape-shifters abound. They can be fascinating in themselves, but they are also important in that they reveal a world of moral fears, metaphysical acts and spiritual encounters that are often more the stuff of social accountability and public authority than the rhetoric and aspirations associated with state building and support for formal legal services in a quest for rule of law. As Judith Verweijen has revealed, in the last few years, scores of thieves and witches are reported to have been killed by "justice populaire" in the Eastern Democratic Republic of the Congo, some being burned alive. ${ }^{4}$ On occasion, formal legal mechanisms are effectively co-opted too, and accusations of magical crimes are made in conventional courts. An attempt was made to do that systematically in parts of South Africa, while in the Central African Republic, a United Nations study of prisons found that more than half of those being held had been accused of witchcraft. ${ }^{5}$

At the very least, events in northern Uganda highlight the dangers of imagining, as is so often proposed, that supplementing formal systems with traditional or community mechanisms is an effective way for governments, civil

3 E.g., A. Ashworth, Madumo, a Man Bewitched (University of Chicago Press, Chicago, 200o); A. Ashworth, Witchcraft, Violence, and Democracy in South Africa (University of Chicago Press, Chicago, 2005; J. Comaroff and J. Comaroff, Modernity and Its Malcontents: Ritual and Power in Postcolonial Africa (University of Chicago Press, Chicago, 1993); P. Geschiere and C. Fisiyi, 'Domesticating Personal Violence:Witchcraft, Courts and Confessions in Cameroon', 64:3 Africa (1994) pp. 323-341; P. Geschiere, The Modernity of Witchcraft: Politics and the Occult in Postcolonial Africa (University of Virginia Press, Charlottesville, 1997); H. Moore and T. Sanders (eds.), Magical Interpretations, Mystical Realities: Modernity, Witchcraft and the Occult in Postcolonial Africa (Routledge, London, 2001); I. Niehaus, 'The ANC's Dilemma: The Symbolic Politics of Three Witch-Hunts in the South African Lowveld, 1990-1995', 41:3 African Studies Review (1998) pp. 93-118; I. Neihaus, 'Witchcraft as Subtext: Deep Knowledge and the South African Public Sphere', 36:1 Social Dynamics (2010) pp. 65-77; H. West, Kupilikula: Governance and the Invisible Realm in Mozambique (University of Chicago Press, Chicago, 2005).

4 J. Verweijen, London School of Economics and Political Science: The Justice and Security Research Programme, The Disconcerting Popularity of "Justice Populaire" in the Eastern DR Congo, 2 December 2013, <blogs.lse.ac.uk/jsrp/2013/12/o2/the-disconcerting-popularity-ofjustice-populaire-in-the-eastern-dr-congo/>, visited on 10 April 2015.

5 N.V. Ralushai, Report of the Commission of Inquiry into Witchcraft Violence and Ritual Murders in the Northern Province of the Republic of South Africa (Pietersburg, 1996); R. Njeng'ere, Reuters, The Dangers of Witchcraft, 4 February 2010, <blogs.reuters.com/africanews/ 2010/02/04/the-dangers-of-witchcraft/>, visited on 10 April 2015 . 
society groups and international agencies to provide access to justice in fragile and conflict affected regions. There is little evidence of these kinds of policies working effectively, for the obvious reason that local customs emanate from very different ideas about accountability than those underpinning conventional legal systems. Nevertheless, an emphasis on selected rituals and customs has often been promoted with determination. ${ }^{6} \mathrm{~A}$ few years ago, activists passionately argued that particular Acholi rituals of forgiving, notably one called mato oput, were a viable alternative to prosecutions, and a basis for opposing the intervention of the International Criminal Court. ${ }^{7}$ Gulu town was the main centre for those asserting this as a viable proposition, but that has not stopped it from also being a location of vigilante acts of punishment. The assaults on the man known as Mr Red are as much a form of contemporary Acholi justice as the drinking of a bitter root and the blood of a sheep to reconcile families in conflict. It makes no sense to take one out of context and imbue it with meanings it has never had in the past, while failing to see or ignoring the other.

\section{Post-Humanitarian Gulu}

Gulu is now a very different place to the way it was when the LRA were still active in northern Uganda. ${ }^{8}$ The night commuter centres for the hundreds of young people who would walk in the town at night to avoid being taken away

6 See e.g., T. Allen and A. Macdonald, 'Post-Conflict Traditional Justice: A Critical Overview', 3 The Justice and Security Research Programme (2013); A. Macdonald, 'Local Understandings and Experiences of Transitional Justice: A Review of the Evidence', 6 The Justice and Security Research Programme (2013); L. Huyse and M. Salter (eds.), International Institute for Democracy and Electoral Assistance, Traditional Justice and Reconciliation After Violent Conflict: Learning from African Experiences, <www.idea.int/publications/traditional_justice/upload/ Traditional_Justice_and_Reconciliation_after_Violent_Conflict.pdf $>$, visited on 14 April 2015, pp. 85-122; T. Kelsall, Culture Under Cross-Examination: International Justice and the Special Court for Sierra Leone (Cambridge University Press, Cambridge, 2009).

7 T. Allen, 'Bitter Roots: The 'Intervention' of Acholi Traditional Justice', in T. Allen and K. Vlassenroot (eds.), The Lord's Resistance Army: Myth and Reality (Zed Books, London, 2010); T. Allen, 'The International Criminal Court and the Invention of Traditional Justice in Northern Uganda', 107 Politique Africaine (2007) pp. 147-166; T. Allen, Trial Justice: The International Criminal Court and the Lord's Resistance Army (African Arguments) (Zed Books, London, 2006).

8 For a discussion of humanitarian agencies in Gulu see T. Allen, 'Life Beyond the Bubbles: Cognitive Dissonance and Humanitarian Impunity in Northern Uganda', in S. Abramowitz and C. Panter-Brick (eds.), Medical Humanitarianism: Ethnographies of Practice (University of Pennsylvania Press, Philadelphia, 2015) pp. 96-118. 
by the rebels have gone, and the reception centres that received back thousands of those who had spent time with the LRA, have mostly closed too. The one that remains hosts the few that are still occasionally sent home from the borderlands of South Sudan and the Democratic Republic of Congo, where the rump of Joseph Kony's forces still operates. At the peak of the war in the years after the turn of the century, well over a million people had been forced to live in appalling conditions in internal displacement camps, dependent on food handouts, and poorly protected by government soldiers. Those have now been broken up. Residents have been encouraged to go back to their villages and reopen their family farms. Land disputes have been an inevitable consequence, and have mostly had to be dealt with in local ways, drawing on notions of customary tenure and usage. ${ }^{9}$ Others have been unable to access arable fields, or have chosen to find other ways to survive. They make for urban centres, especially Gulu.

Many of the humanitarian aid agencies based there have now left, but the town has continued to attract investment. It is on the main road to South Sudan, where an oil-driven economy has provided a market for Ugandan imports. Gulu also has a new, but relatively successful university, and hotels built for expatriate humanitarian staff have continued to expand. In addition, Gulu has become established as the home of the Acholi Paramount Chief, with a palace and a government that was set up in 2004, charged with promoting traditional ways of life, and for a while, taking a lead in promotion of local rituals as part of the reconciliation and rehabilitation process. There are now several cafes where it is possible to drink a cappuccino, a sizeable supermarket which sells bottles of wine, muesli and electronic equipment, and other new shops selling thousands of pirated DVDs. It remains a place where religious beliefs are strong. Both the Anglican and Catholic churches have an important presence, and so do many new forms of Christianity, which emphasise personal experiences of the spirit world. Pentecostalism is prevalent, and so is becoming 'born again' after divine encounters. Gulu has actually become something of a place of pilgrimage. Groups of Christians arrive from time to time from the United States and elsewhere to share in lively prayer 'crusades'. Some stay for a while to assist projects for war-affected people, especially children, and to evangelise.

9 J. Hopwood, Elephants Abroad and in the Room: Explicit and Implicit Security, Justice and Protection Issues on the Uganda/South Sudan Border, 22 Justice and Security Research Programme (2015); Human Rights Focus, United Nations Peacebuilding Programme in Uganda, Land Conflict, Monitoring and Mapping Tool for the Acholi Sub-Region: Final Report, March 2013, <www.lcmt.org/publications.php >, visited on 10 April 2015. 
The mass of the mainly Acholi population has a tangential connection with these developments, which is not to say that they are unaffected by them. Life for large numbers of them in the years since the war effectively ended at the time of the Juba Peace negotiations of 2006-2008 has been hard. Those drifting to the town have generally struggled to find work or fees for education. An occupation for scores of young men is to work as a motor-bike taxi driver. These taxis are known as boda-boda and have become much more prevalent throughout the town than hitherto. Many of the drivers are returnees from the LRA. Others have moved to Gulu having grown up in displacement camps. They are not unpopular, in that they are relied on for cheap transportation, but they can be a focus of suspicion. That is because they are mobile, have a bit of money, sometimes move around at night, have a degree of independence and often operate in groups. Also, there have been widely reported incidents of boda-boda drivers being involved in robberies, rapes and murders. ${ }^{10}$

More generally, the migrations and upheavals in and around Gulu mean that strangers are thrown together, and there are suspicions about lajok (a kind of sorcerer who uses magic and the force of their ill-will to do harmful things to people), as well as the use of witchcraft and magic by local healers/diviners, especially those possessed by spirits (ajwaki). Alleged thieves and marginal individuals are ostracised, and occasionally attacked. In one incident, in November 2013, a man was hacked to death in the night by a mob outside the house in which I was sleeping. Those asked about it said that "he did good to die". ${ }^{11}$ Here, in the place where there has been so much emphasis on ostensibly traditional Acholi rituals of forgiveness, violent forms of vigilante justice are on the rise. Indeed, the current Mayor of Gulu (Local Council 4) is well-known for supporting extrajudicial killing of suspected armed robbers.

Moreover, where customary measures are applied, 'forgiveness' is not really the appropriate term. Efforts are made to promote and preserve a semblance

Red Pepper, 'Gunmen Attack Zawadi Bus in Amuru, Rob Millions', 5 December 2014, <www .redpepper.co.ug/gunmen-attack-zawadi-bus-in-amuru-rob-millions/>, visited on 10 April 2015; Acholi Times, 'Gulu Boda Boda Operators Castigate Police', 19 November 2012, <http://www.acholitimes.com/index.php/news/acholi-news/1034-gulu-boda-boda -operators-castigate-police-over-murder-investigations >, visited on 10 April 2015; Acholi Times, 'Suspected Motorbike Thief Survives Lynching', 17 June 2013, <acholitimes.com/ index.php/health-matters/8-acholi-news/1495-suspected-motorbike-thief-survives -lynching-by-angry-boda-boda-operators $>$, visited on 10 April 2015.

11 H. Porter and R. Tapscott, London School of Economics and Political Science: The Justice and Security Research Programme, (In)security Groups and Governance in Gulu, Uganda, 3 April 2014, <blogs.lse.ac.uk/jsrp/2014/04/03/insecurity-groups-and-governance-in-gulu -uganda/>, visited on 10 April 2015. 
of moral order, without recourse to formal systems, which are invariably expensive and are decided in favour of whoever has the necessary contacts to pay the most. One consequence, as Holly Porter has shown, is that women who have been raped rarely turn to formal legal mechanisms, even though they know about them and potentially have access to them. ${ }^{2}$ In a randomly selected sample of 187 women interviewed in two locations, one located close to Gulu town and the other in a more rural area, she found that 76 women had been raped, several more than once. The focus is on the maintenance of social cohesion, and the imposition of what Porter calls "social harmony". ${ }^{13}$ A consequence is that women commonly have no option other than to go on living nearby their rapists, even in the same home.

Meanwhile, the few women and men who have funds, and can afford to secure what they need, including property and legal rulings, can find themselves suspected of foul deeds. If, for some reason, they become unpopular, tales are likely to be told about what they must have done to have secured such relative wealth. Perhaps they sacrifice victims as part of a pact with satanic forces, use human body parts for unspeakable rites, or turn their neighbours into zombies and make them work in their fields as labourers at night, or have gone 'beneath the water' (te pii) to obtain bad magic - or have employed ajwaki to do so on their behalf. In all instances the suggestion is that these evil practices explain how resources and energies are sucked from others for egregious accumulation, or are used to attain power and influence. Not surprisingly, this is an aspect of formal politics. During the elections for the position head of the District Council (Local Council 5), the opposition candidate and eventual winner reported an attempt to have him killed through witchcraft. A woman had rung him to tell him that "a group of people who appear to be his political opponents had paid 1.5 million shillings [about 500 USD] to a witchdoctor with instructions to kill him before the elections". According to a local radio outlet, the police had launched an investigation. ${ }^{14}$

Strong belief in magical and supernatural phenomena was also apparent among many of those I interviewed after they returned from the LRA in 2004 and 2005. They recounted as facts, and occasionally with manifest fear and

12 H. Porter, 'Justice and Rape on the Periphery: The Supremacy of Social Harmony in the Space Between Local Solutions and Formal Judicial Systems in Northern Uganda', 6:1 Journal of Eastern African Studies (2012) pp. 81-97.

13 Porter, supra note 11.

14 Uganda Radio Network, Gulu LC5 Candidates Reports Use of Sorcery in Campaigns, 28 January 2011, <ugandaradionetwork.com/a/story.php?s=31204\#ixzz3WF3tvcDL $>$, visited on 10 April 2015 . 
respect, incidents of Joseph Kony reading the minds of his followers, and predicting events after consulting the spirits possessing him. The control exercised, and the terror he evoked, stemmed in large part from his knowledge and access to dangerous, amoral and highly potent spiritual forces. These ideas are easy to dismiss as nonsense, however, as White observes about vampire stories in African oral history, people construct and recount stories that carry the values and meanings that most forcibly get their points across - verifiable facts may not matter. ${ }^{15}$ In addition, repeating of the stories may have social effects, making them collective truths, even experiential truths. For those telling these stories, there is not necessarily a clear distinction from experiential truths associated within Christianity, such as the Pentecostal 'speaking in tongues' common in Gulu's churches, or for that matter, the visions of the Virgin Mary that are said to have occurred in the northwestern Ugandan township of Lodonga in the diocese of Arua, which were confirmed as a Catholic miracle in 1961. Stories can be inspirational as religious events, or they can be threatening. When they are threatening, the fear is real, widely shared, and moral panics can ensue.

White gives numerous accounts of blood-suckers or 'vampires' that resulted in popular uprisings and vigilante acts in colonial times. Often the stories were linked to wealth allegedly accumulated by Europeans and migrants, especially semi-skilled workers. Those who drove vehicles and car mechanics were especially suspect. White also notes that, unsurprisingly, the introduction of biomedical processes, notably those involving blood transfusions and blood testing took on local meanings, and so did Christian teaching on drinking the blood of Christ and eating his body. ${ }^{16}$ As colonial officials found, a difficulty in dealing with these kinds of accounts of blood-sucking is that denying them or dismissing them tends to have counterproductive effects. Far from disproving them, the effect can be to add publicity, and effectively corroborate them.

The latter is particularly the case when those providing counter-arguments need to make claims of their own, which also requires the belief in peculiar or spiritual notions, such as what occurs during the Eucharist ritual. Heike Behrend, has shown how Catholic strategies in Western Uganda from the late 1990s aimed at repressing forms of paganism in practice promoted their evolution and spread. With the help of the Holy Spirit, lay Catholics identified witches who turned people into zombies and then ate them. In so doing

15 White, supra note 2, p. 30.
16 Ibid., p. 191. 
they affirmed the reality of the practice, causing widespread panic. ${ }^{17}$ Subsequently, reporting on the radio and in newspapers has further exacerbated the problem, with reports of 'scary' cannibal stories being exposed in many districts. ${ }^{18}$ The availability of Behrend's book in Uganda has been a factor too, being quoted as if she herself believed the horrific tales of satanic acts and human sacrifice she reports. ${ }^{19}$

Matters are quickly exacerbated when news media become involved. In Uganda, English is widely spoken and there is access to a variety of newspapers in urban locations, growing use of the Internet, and pervasive access to radio stations in local languages as well as international channels like the B BC World Service. Many bars and restaurants in the big towns additionally have televisions, and show the World news channels, as well as football matches. In addition, mobile phone signal coverage is remarkably good. In such circumstances, moral panic can be triggered at a national level when linked to propaganda campaigns. The role of radio in the demonising Tutsi at the time of the Rwandan genocide, and thereby promoting genocidal slaughter is one wellknown instance, and there have been many others. In Uganda, the persecution of homosexuals has been connected with moral panics that have actively been promoted through the news media. Similarly, the weirdest qualities of the LRA were a particular focus of news coverage of the war in both the Ugandan and international media, contributing significantly to Joseph Kony's alarming reputation and to social effects, such as mass population movements.

Even where the intention is to just provide information, health education, or to raise awareness, news can confirm and amplify things in unexpected ways. Thus, public health campaigns dealing with HIV/AIDS have compounded historical fears connected with collecting blood. In the 1980s, rumours circulated in affected parts of Africa that certain cars have special straps to suck blood to be used for transportation of unpolluted blood to places where cleaner, foreign blood was desperately needed. ${ }^{20}$ Also, promoting awareness of HIV/AIDS

17 H. Behrend, Resurrecting Cannibals The Catholic Church, Witch-Hunts and the Production of Pagans in Western Uganda (Boydell \& Brewer, Woodbridge, 2011).

18 New Vision, Scary Cannibal Stores Exposed in Many Districts, 23 September 2013, <www .newvision.co.ug/news/647529-scary-cannibal-stories-exposed-in-many-districts.html>, visited on 10 April 2015; New Vision, Cannibalism is in Rumours in Hoima, 12 October 2013, <www.newvision.co.ug/news/648322-cannibalism-is-in-rumours-in-hoima.html>, visited on 10 April 2015.

19 New Vision, The Priest Who Was Nearly Eaten, 21 October 2013, <www.newvision.co.ug/ mobile/Detail.aspx?NewsID=648621\&CatID $=396>$, visited on 10 April 2015.

White, supra note 2, p. 130. 
via radio messages spread fears of people who look normal, but are secretly harming others, thereby confirming and spreading local ideas about witches. At the same time, the Catholic Church was much involved in the HIV/AIDS awareness campaigns and was promoting moral behaviour as the best solution. In parts of northern Uganda in the late 1980s and early 1990s, terms for forms of witchcraft and HIV/AIDs became synonymous, and were used to justify local council involvement in violent witch cleansing incidents.

In Arua Diocese, the region in which the Virgin Mary had appeared, the Church responded to the stories of witches by campaigning against satanic practices, and went so far as to print the names of persons accused in the newsletter distributed at services. An effect was to give a degree of legitimacy to attacks on alleged witches and several killings. ${ }^{21} \mathrm{~A}$ subsequent development among the Madi, whose home districts are immediately to the west of Gulu, was the introduction in 2006 of 'elections' for suspected witches, whereby each member of the neighbourhood voted for those individuals they thought were witches under the auspices of local councils. Votes were counted, just like in other elections, and the results recorded. Those with the most votes were then held to account in a local council meeting, and were severely punished. Most were chased away, and their property destroyed or confiscated. ${ }^{22}$ It was a version of this kind of hybrid mechanism that was adapted to deal with Mr Red.

Another media fed moral panic in Uganda, which again relates directly to the Mr Red case, is the perceived rising incidence of child sacrifice. It is the case that children sometimes disappear in Uganda. Thousands were abducted by the LRA. Also, where there are conflicts over land, and children are seen as having a potential right to inherit it, there may be pressures to remove them. Others just move to towns and loose contact with relatives. However, there is also some evidence that witchdoctors may use the body parts of children, although that evidence is limited and contradictory. According to a report published in 2013, one child is sacrificed every week in the 25 locations

21 T. Allen, 'A Flight from Refuge: The Return of Refugees from Southern Sudan to Northern Uganda in the late 1980s', in T. Allen (ed.), In Search of Cool Ground: War, Flight and Homecoming in Northeast Africa (James Currey, Oxford, 1996) pp. 220-261; T. Allen, 'The Violence of Healing', 47:2 Sociologus (1997) pp. 101-128; T. Allen and L. Storm, 'Quests for Therapy in Northern Uganda: Healing at Laropi Revisited', 6:1 Journal of Eastern African Studies (2012) pp. 22-46.

22 T. Allen and K. Reid, 'Justice at the Margins: Witches, Poisoners, and Social Accountability in Northern Uganda' 34:2 Medical Anthropology (2015) pp. 106-123. 
surveyed. ${ }^{23}$ This compares with seven cases of child sacrifice reported to Uganda Police in 2011 and ten in 2013. ${ }^{24}$ Even the low figures are obviously cause for concern, and a host of aid agencies and Church groups have launched campaigns against the practice. Inevitably these organisations have needed to publicise their activities, both inside Uganda and internationally, to secure funding. There are also journalists and news outlets that have jumped on the media possibilities of a new African horror story, publishing exaggerated accounts.

A proliferating number of accounts began appearing in Ugandan print and electronic media around 2008. The story was then quickly picked up in the international media, with shocking articles in the United Kingdom's The Observer and The Independent newspapers in 2009. The latter quoted Nsaba Buturo, the minister for ethics and integrity, who blamed the murders on witchcraft. "Witchdoctors", he said, "prey on people's fear and greed for riches". ${ }^{25} B B C$ reports in 2010 then elaborated on the story, with, it would seem, an eye for a United Kingdom domestic audience willing to believe almost anything about Africa. A filmed report was shown on Newsnight, the flagship $B B C$ news channel, and versions were also broadcast on the Word Service radio and $B B C$ World television in Uganda. The television report was particularly salacious and misleading. It suggested that thousands of children are sacrificed because of a deeply rooted belief system, and proposes that witch-cleansing, targeted at witchdoctors, is currently the most effective strategy for preventing it.

Scholars working in Uganda noted that the account was a disturbing mixture of half-truths and nonsense, displaying questionable journalistic ethics. ${ }^{26}$ An investigation in Uganda occurred, and confirmed that many of the details were inaccurate, but that did not stop the radio version from being awarded an international prize. ${ }^{27}$ It was a story that was hard to set aside. Somewhat more

23 Humane Africa, Child Sacrifice and Mutilations in Uganda, April 2013, <www.whrin.org/ wp-content/uploads/2013/04/Child-Sacrifice-and-the-mutilation-of-children-in-Uganda .pdf>, visited on 10 April 2015.

24 The Guardian, 'How One Charity is Working to Prevent Child Sacrifice in Uganda', 4 March 2015, <www.theguardian.com/global-development-professionals-network/2015/mar/o4/ child-sacrifice-uganda-mutilation-witch-doctor $>$, visited on 10 April 2015.

25 Legal Aid Board, Refugee Documentation Centre of Ireland, Uganda, 12 February 2010, <www.justice.gov/eoir/vll/country/Ireland_refugee_DC/uganda/ritual\%2okillings.pdf >, visited on 10 April 2015.

26 A. Kuper, 'Bizarre Rumours', London Review of Books, 12 January 2010, <www.lrb.co.uk/ blog/2010/o1/12/adam-kuper/bizarre-rumours/>, visited on 10 April 2015.

27 One World Media, Awards 2010, < archive.oneworldmedia.org.uk/awards/previous_awards/ 2010/>, visited on 10 April 2015 
measured reports by the $B B C$ and other international media outlets have followed, and so have reports in the Ugandan media, including in the government's New Vision newspaper. ${ }^{28}$ Posters sponsored by several organisations, including Plan, World Vision, Save the Children and various Christian institutions have been put up in places thought to be most affected. One proclaimed, "No Wealth from Child Sacrifice - Condemn the Practice". The implication was clear - there are lots of people in Uganda who are doing it. This helps explain one of many odd aspects of the case presented below. All the dead bodies that have been found are adults, yet Mr Red is most notorious for allegedly sacrificing children.

One last point, before turning to the details of Mr Red's story. A few of those explaining events made explicit reference to victims being killed in the way vampires kill in popular films and television series. As noted above, another change during the last few years is that pirated videos are readily available in Gulu's DVD shops, and relatively cheap electronic equipment is sold in the supermarket. Watching DVDs is popular among many living in parts of the town with electricity, and ideas drawn from them come up in conversations with the urban elite. The DVD shops have thousands of discs available, including the complete 'Vampire Diaries', 'Buffy the Vampire Slayer' and the 'Twilight' movies. In mid-2014, a feature film called 'Black Water Vampire' was on display in one of them. It is about brutal killings known as the Black Water murders. Perhaps the circulation of these DVDs has played a part in the ways rumours developed. In particular, the reference to evil coming from water may have resonated with the idea of avaricious people going 'beneath the water', although no one made that link with the DVD explicitly. In general, it is hard to know how much ideas in the DVDs were a factor in the spreading or elaborating of rumours, but it probably had something to do with the references to strange holes in the necks of victims. An additional twist was that the actress who played Faith in 'Buffy the Vampire Slayer' made a publicised visit to Gulu at the time, in support of an NGO run by her mother. There was comment about that in relation to Mr Red, but more as an amusing coincidence than anything sinister.

28 New Vision, 'How My Son Escaped Child Sacrifice', 19 October 2013, <www.newvision .co.ug/news/648558-how-my-son-escaped-child-sacrifice.html>, visited on 11 April 2015; New Vision, 'Buikwe, The Child Sacrifice Capital', 24 November 2014, <www.newvision .co.ug/news/662152-buikwe-the-child-sacrifice-capital.html>, visited on 11 April 2015; New Vision, 'Witchdoctor Arrested Over Child Sacrifice', 18 February 2013, <www.newvision .co.ug/news/639944-witchdoctor-arrested-over-child-sacrifice.html>, visited on 11 April 2015 . 
The first of the murders associated with Mr Red occurred in late 2013, and the last involving a confirmed corpse in April 2014, although there were rumours of others. Five bodies were all found at a place called Akonyi Bedo, a few kilometres outside of town. Even before the last of these killings, the President's representative in Gulu, the Resident District Commissioner (RDC), called a meeting of people from all the affected locations. Everyone was told to tell the truth, and write the name of the person responsible on pieces of paper.

Those interviewed suggest that was done in much the same way as the voting for witches described above in the Moyo and Adjumani Districts (although it was additionally noted by one knowledgeable Acholi from the region that the procedure resonated with old customs of kwir, which had been banned under British rule, whereby members of a community would decide who was responsible for witchcraft by allocating pebbles to suspects at a meeting). The names given were counted and, although it seems the results were not openly released, according to those interviewed more than ninety per cent voted for a particular person. He was a man who reportedly wears red all the time, including his shoes, his shirt, his pants, trousers and even his watch. He was taken to the police station, but it was impossible to find the necessary evidence for formal prosecution. The District Police Commander (DPC) and two opposition Members of Parliament also visited the affected locations. They encouraged local mobilisation to deal with the threat. When interviewed, one of the opposition M Ps explained that she had told people to only sell land to good people. The family of this Mr Red had bought land, but since he is bad, she argued, it could be taken back. Mr Red was supposedly chased from his former residences because of his immoral acts, so it was appropriate to do the same thing.

On the occasion of the funeral of one of his alleged local victims, a mob of about 40 people, including local councillors, went to his home and attacked it. They smashed and burned everything, killing all his goats, ducks and chickens, and destroying all his crops, including his large maize field and his orchard. His brick house was completely ruined, his pick-up truck overturned and his motorcycle broken too. Even his pool-table was targeted. Mr Red was not present at the time, but it was anticipated he would want revenge, or perhaps just more blood. The DPC and the RDC had told people to protect themselves, so groups of youth were organised for the purpose. Unfortunately, this led to serious nocturnal clashes.

There were concerns that some boda-boda drivers (i.e., drivers of motor-bike taxis) were in some way in league with Mr Red, or perhaps acting on his orders. Village councils created local security groups, made up of young men, and curfews 
were imposed at night. Those who were moving about in ways that might be considered suspect were stopped at road blocks, and those arrested were handed over to the police or made to pay 'fines'. Adversely affected boda-boda drivers complained to the police that people were patrolling illegally, without official control. Tensions increased when some youth security groups beat-up those they had caught, and there were accusations to the police that they were, in reality, just robbing people. In one encounter, the police became directly involved, panicked and opened fire, killing one man and seriously injuring another. Relatives and neighbours of these individuals asserted that killing follows Mr Red. He is the one responsible even if the police did the shooting. Blood follows him. Conversations with a variety of government officials, both elected and appointed, told much the same story.

Mr Red himself was known to have taken refuge in town. Many of those interviewed were open about wanting him dealt with by the police or in some other way. They were incensed by the possibility that people who had destroyed his property might have to pay compensation. Mr Red, it was claimed, liked red, because he liked blood so much. He will never have enough. Some described him in Acholi as a malevolent sorcerer who uses magic or a malevolent force to do harmful things to people. Others said he was a person who goes "under water" (te pii) or is in league with evil under water people. As has been explained, this indicated that he was someone who was accumulating wealth by engaging in witchcraft activities, probably by working with a bad ajwaka, who will use her (or occasionally his) magical skills to assist him in return for payment. Those payments might be in the form of money, but they may be more onerous or wicked. It was alleged that they could include the sacrificing of individuals, including children, and possibly the use of their body parts in evil rites. There was additionally much discussion about Mr Red removing his victims' blood and possibly their brains.

While I was researching these matters, a further development occurred that placed Mr Red in even more danger. An incident occurred at the Anglican Church in the centre of town during the Sunday, 7:0oam service on 24 August 2014. The Bishop of Northern Diocese called a young woman to the altar. He greeted the congregation and said, I have come with a young lady who is 23 years old. She was an ajwaka (witchdoctor), but now she is a 'born again' Christian. The Bishop then asked the ajwaka to give her testimony. Accounts varied about what was precisely said, but the gist of it was that she had known Mr Red when she was a practising ajwaka, and that he had rung her mobile phone to tell her that he had "finished another one" each time he killed. Eventually it was possible to find a reliable informant who had actually attended the church service. This is his account, taken from an interview in the 
Acholi language given to Jacky Atingo, one of my Ugandan co-researchers. The ajwaka's story was also reported in Acholi on the local FM radio station.

The ajwaka began by explaining that she had experienced her spirit (jok) since she was a baby:

... my mother had gone to dig. She left me under a tree to sleep, but when she came to check on me she found very many snakes over my body. My mother called people. Then later I was taken to an ajwaka and the ajwaka told my mother that the spirit I have wants me to become an ajwaka ... In total I had four jogi [spirits] ... People would come from Bombo [a faraway place] for consultations. In a day I would earn 800,000 shillings [more than $180 \mathrm{G} \mathrm{BP}$ ]. Some of the Mothers' Union representatives from this church would go to me, in their struggle for leadership.

Apparently, at this point, everyone in the church was silent waiting to hear whether she was going to mention the names of those in the Mothers' Union who went to her for consultations and to obtain magical medication that would enable them to become leaders. Instead she started talking about Mr Red:

People like Mr Red would come to me. One time he called me to say that he has now killed six people. I told him not to kill people because my spirits do not want the killing of innocent people ... I became 'born again' because my spirits [i.e., those possessing her] have started demanding for blood. They wanted me to sacrifice my first-born child. The spirits were saying they are already tired of chicken and goat blood, this time they wanted my child ... I had already made up my mind to get saved. My family was not happy with me, so the Bishop decided to bring me to Gulu to stay at his home ... When Mr Red heard that I was 'born again' he called my phone and said I should not be. He still wanted to show the power of witchcraft.

At the end of her testimony, the Bishop concluded by saying that there were other devil-worshippers who should be avoided, including the father of the famous spirit medium known as Alice Lakwena. The congregation should be careful of the church he runs in the town. The bishop also made it known that the ajwaka was now under his protection. He subsequently travelled with her to speak at various churches in the diocese. At these events, she repeated the story, and added that many people had come to her for advice when she was a 
practicing ajwaka. He said she would not reveal their names in public, but they should know that that she could do so, and they should confess, repent and be saved. She and the Bishop then did 'altar calls' and several people came forward to renounce drunkenness and witchcraft.

The converted ajwaka' statements seemed to confirm Mr Red's guilt, and placed him in an extremely difficult position. Additional rumours began circulating, focussing more on child sacrifice. It was said that Mr Red had buried the remains of a child in the swamp near the Uchumi supermarket in town. Perhaps significantly, Uchumi's colours are red. Knowing that something was likely to happen, Atingo was asked to take notes at the service herself on Sunday, 7 September 2014. This is her account:

Everyone was wondering why I was writing everything Mr. Red was saying all over my Bible ... I saw the bishop arriving in church ... Mr Red walked in with his brother. I would say the brother just sneaked in with him. Some people in church knew him, others did not. Those who knew him started whispering, including a man seated next to me. He asked, 'What is Mr Red doing in our church?' Then after a song, the Bishop said, 'Today we have a special guest in the church'. It was Mr. Red. Some people clapped their hands. Others murmured, "He is a killer". The Bishop continued, saying Mr Red is now 'born again.' The congregation kept on talking. Then the Bishop said, 'If someone has never sinned let him or her be the first to cast the stone or condemn Mr. Red'. He also said, 'Jesus came and died for sinners like me and Mr. Red, not for clean-hearted people'. He told us that, when a person confesses their sin to God and is born again, all his or her sins are washed away. The church was in a total silence. The Bishop then said that a few days ago he had gone to Mr. Red's house and asked him to confess his sins and be saved. Mr Red had decided to become born again. Then the Bishop invited Mr. Red to come to the altar and talk to the congregation ... Mr. Red came up and said that he had become born again. But not that he had done what people are accusing him of. He feels people have rejected him over nothing. He has not killed anyone. He went to an ajwaka when his son had epilepsy to consult for treatment. He asked God to forgive him for going to a witchdoctor for his son's sickness. He asked God to forgive him, if that is sin. He also said that one time when he was in Amuru for construction work, a particular animal called jwee [possibly an otter] was killed. He decided to smoke the meat because in Acholi tradition they say that its meat is used as medicine for losing weight ... Police came to check his house, because, they said, he puts on red clothes and is a killer. They found the dried meat and 
took it away. They found that it was not the meat of a human being. But the rumours spread in town that they had found a dried human corpse in his house. Mr Red said if keeping the meat of jwee was a sin, then God should forgive him. The congregation started murmuring, saying that he is not yet 'born again' because he has not confessed his sin. Some people were really upset; they wanted him to accept his crime. Then Mr Red said he had started putting on red clothes during Obote's time [i.e., the 1980s]. He likes red in general, but there is no evil thing associated with him wearing red clothes. After this, the Bishop asked the congregation to stretch out their hands and pray for Mr. Red. He accepts Christ as his personal saviour. We all stretched our hands and prayed for him. One of Mr. Red's brothers is a choir member in the church and I think he had a lot of pressure on him from the bishop. Currently the bishop is moving with Mr Red and Mr Red is staying at the bishop's house.

The Bishop was clearly pleased to have Mr Red at his services. It provided opportunities for more 'altar call' conversions. It also provided a degree of protection for Mr Red, although that did not last long.

Towards the end of the year, the Bishop became busy organising the international celebration for Archbishop Janani Luwum Day in Kampala. Luwum, the head of the Anglican Church who had spoken out against Idi Amin's brutal regime, was also a leader of the 'born again' movement in the Anglican Church, of which the Bishop of Gulu was such a keen follower. At the same time, $\mathrm{Mr}$ Red, or "Mzee Red" as he was called in the Acholi news media, was accused of more crimes. There were several stabbings over the Christmas period, and on 4 January 2015 one of those attacked said her attacker was Mr Red, who had moved to that area of town with his wife and young child. A group made up of people from the neighbourhood in which that stabbing occurred responded by collectively going in search of Mr Red, allegedly with the intention of lynching him. Hearing the mob calling out his name, Mr Red went to the police station to ask for help. The response was to arrest him without charge and put in prison. It was explained by the police that this was done for his protection.

Atingo and another researcher, Dorothy Atim, made some enquiries about these events in the neighbourhood. It seems that there had been three deaths and six people injured in attacks. The assailants had used machetes. All the incidents had taken place after Mr Red had moved to that location. Many of those spoken to did not directly link the incident to acts of instrumental violence by Mr Red. Some blamed thugs. However, there was a view expressed that, even if Mr Red did not do something deliberately, his presence sets evil in motion. 
During January 2015 and in subsequent months, there were magistrate court hearings in Gulu, at which the man known as Mr Red was charged with unlawful wounding. However, no witnesses turned up in court. As a result, the police made an announcement that no one should harm him once he was released, but that anything suspicious should be reported. Almost immediately, another mob evicted a woman who was renting a property from Mr Red in town. She was alleged to be having sex with him. The local media have been covering the case, and the real name of man accused of being Mr Red has appeared in the main Acholi-language newspaper. At the time of writing he is still alive. He has now left prison, but stories of him needing blood and sacrificing children continue unabated.

The person accused of being this evil Mr Red is an overweight former employee of the Ministry of Works called Charles Apire. His ancestral home was in Patiko, about an hour's drive from Gulu, but he had been employed in the town and other parts of Uganda as a mechanic. After an accident, he had retired on a pension, running a small workshop in Gulu and a couple of others shops. He owned vehicles and various electronic items. In addition, he had purchased some property in Gulu, which he rented out. His main residence was outside the town, in Akonyi Bedo. Here he built a brick house with a corrugated iron roof and a bar, which boasted a pool table. It is mostly surrounded by cultivated land, but his compound adjoins that of a well-looked after dispensary, run by the Orthodox Church, with funding from the United States. Around Apire's house was a fenced plot, and he had a thriving farm. Other members of his paternal family had also moved from Patiko. Some of his paternal uncles, who had also have farms in the vicinity live nearby his home. Apire himself is a Catholic, married to a woman who runs one of his shops in Gulu. In local terms, is he is a wealthy man.

He was staying in Gulu town when I interviewed him in August 2014. He was keeping a low profile, but it was quite easy to locate him with the help of Tonny Labol, a well-connected Acholi friend and long-time co-researcher. Apire spoke to Labol and me in a comfortable room with a fridge in one corner and television in another. His young son was eager to listen to the conversation, but would sometimes jump up and fiddle with the television until his mother told him to turn it off. Around the walls were numerous photographs in frames and various Catholic images. The colour red was noticeably missing. It only appeared in a few of the pictures, notably one depicting Jesus. Some of the 
cushions on the sofa and chairs had no covers. Apparently they had been red, but had been removed by the police as evidence. He gave his account of events in English, sometimes with further elaborations in Acholi.

He began by saying that all that had happened was like a kind of miracle. By saying so, he seemed to mean it was beyond understanding, and also that it was amazing that he was still alive. He showed me photographs of his destroyed property and listed all the things that had been lost. All his animals had been burned to death, and he lamented in particular the loss of his pickup truck, on which he had relied for many things. Now he did not have enough income to pay his son's university fees. No explanation had been given to him for why the police did nothing to stop what happened. No one had been arrested. Also, he complained that no one has told him why they did it. They have impoverished him, and now he lives in fear. He had recently been found in Gulu town by one of those involved and had been threatened with violence if he tried to seek compensation or take any action against those who had attacked him. That man had been angry that Mr Red had asked the police to act. According to Mr Red, he said, "I am going to kill you today". Eventually he was made to go away, but Mr Red was worried that he might come back at any time. He knows who those who hate him are. They are maternal relatives who want his land. It was, he believed, one family that was the main source of all his difficulties. He had bought 17 more acres of land in Akonyi Bedo. The traditional chief of the area, he explained, had allocated him the land because of his good behaviour, but that family had become jealous. There had also been a dispute over the placement of a road. Apparently this had been with a woman who was a councillor to the Gulu mayor. She wanted a road moved from her land to his, but as he had a land title and marking stones, she wasn't allowed to move it.

Apire showed photos of himself as a boy, wearing red clothes. He explained that he usually put on red things, because he liked the colour. It was no more than that. In the pictures, his clothes are actually a mixture of red and other colours, and he was not wearing red at the time of the interview. He also shared with us the official reports from various investigations that that had occurred before the mob came to his home. Warrants had been issued, and police had searched all his properties. They had refused to say what they were looking for, and confiscated some items, but nothing was recovered that was of use for investigations. Apire maintained that when the RDC and the MPs went to Akonyi Bedo to investigate, they heard nothing against him. People just said: "Mr Red brought development to our place". However, in an interview that Apire had given to another researcher, Sophie Hooge Seeback, earlier in the year, he had explained that the councillor to the mayor had been present, and that she was the one who started "spoiling his name". She had spread rumours 
about the discovery of a "preserved child". Apire asserted repeatedly that he is innocent of all of the things being said about him. Just like everyone else, he had been worried by the spate of murders. Like others, he had voted in the election called by the RDC to identify the culprit, but had said he did not know who it was. He had no idea why others chose to vote for him. "In Uganda", he concluded, "we have human rights. People cannot act if there is an ongoing investigation. The police will take those people to court".

When this version of events was repeated to others, a common response, even from senior officials, was that with police investigations, people are innocent until proven guilty. That meant it was necessary to deal with Mr Red in other ways. It was striking that no one seemed at all interested in specific details that might be significant. He must be doing something bad to be so successful. His relative wealth, his red clothes and the suspicions of neighbours revealed that something shady was going on. The opposition MP that Labol and I interviewed was surprised when she was told that it had been possible to meet Mr Red and discuss the case with him. She was even more amazed to know he was married and had children. She had quite a different notion of what such an evil figure would be like. However, she remained disinterested in finding out how the murdered individuals were actually killed. No one appeared to think that was relevant. Yet, it was easy to discover that things were less weird, if no less awful, than was being claimed.

A visit to Gulu hospital produced the name of the doctor who had performed the post mortems. He was easy to find in the town, and was more than willing to talk about what he had seen. He seemed pleased that someone had finally bothered to ask him. To begin with, the claim that the blood of victims had been sucked out was nonsense. There was plenty of blood in the victims, and there were no holes in their necks. A blow to the skull killed them, probably from a hexagonal-shaped hammer behind the left ear. To do this would have required someone to wield the hammer and someone else, possibly two people, to hold the victim in the right place. It seems as if the bodies were moved from where they were attacked, and then placed in their beds with a sheet over them. Four of them were reputed to have been marginal men who lived alone, and were said to be drunk quite often. They had been killed between 7 and 25 December 2013.The fifth confirmed murder, however, was something of an exception. Oketa Balasio had been found dead on 22 April 2014, and he was married. As far as the doctor was aware, whoever killed these individuals, and what the motive might have been, remains a mystery.

It was the Sunday after this interview that things became even worse for Apire. That was when the Anglican Bishop invited the converted ajwaka to the altar in the main church in town and she accused Mr Red of phoning her each 
time he killed someone. Given the threats that had already been made on Apire's life, Labol and I decided to intervene. We began by tracking Mr Red down again to see what he had to say. It was a little harder to find him this time. He had heard about what had happened, and gave assurances that it was not true. He had never rung that woman. He had consulted an ajwaka when his son was ill. Also, when he had tried to lose weight, an ajwaka had told him that this might be possible if he ate the smoked meat of an animal that he called ngonge. He described this in such a way as to suggest it was an otter. He had kept the dried corpse in his room, and maybe it was that which people believed was a sacrificed child. Concerned for Apire's safety, it was decided to speak to the Bishop in the hope that he might make an announcement that would lessen the impact his former ajwaka's testimony, and to find out why he thought it was appropriate to make such allegations at a public meeting.

The Bishop was interviewed in his Gulu office, just outside of town. The story of Mr Red was recounted to him, and he was obviously annoyed by it. He admitted that the young woman was staying with him and was under his protection, but took no responsibility for the possible dangers her testimony posed for those implicated. "They were all one", he claimed, "they were together". When asked if he had checked to see if she had any calls from someone on the days of the murders, he became angry. "I do not agree with child sacrifice". He asserted, "You don't know what these people do. They are all one, all working together." It was explained that our concern was that a possibly innocent man was being accused without evidence. The Bishop seemed not to believe that it had really been possible to meet with Mr Red, and he ended the conversation saying Mr Red should be brought to his office, if he really was in town, and he could then speak to the ajwaka. They could agree everything and then Mr Red could ask for forgiveness and become 'born again' too. It was pointed out that Mr Red was a Catholic, and might not want to be 'born again' in that way. He might just want clear his name. The bishop was not convinced.

It seemed that there was no option at this point other than to try to force the issue. Reporting back to Mr Red about what had occurred, it was suggested that he accompany us to the Bishop's office. Apire suggested doing so with two men who look like him. Then the ajwaka could show if she really knew the person she says she worked with. The group then returned to the Bishop's compound, somewhat surprising him. However, he would not allow Apire and his friends to meet with the ajwaka, because then it would become "like a court of law". He proclaimed, "If the real Mr Red is here, let him say so and then go to see her". It was pointed out to the Bishop that if that happened, it would be like saying that he was the guilty person. Would it not be 
reasonable for the ajwaka to select the person who she claims was her close collaborator? The Bishop responded by saying that she had only spoken on the phone to him, so would not be able to do that, and he was adamant that no meeting could take place unless the real Mr Red identified himself. At this point, it was decided that nothing could be done, and that we should leave.

On the way back to town, we discussed a different strategy: the only way of making the Bishop allow a meeting was to bring the local press. The story of the ajwaka's testimony has been reported on the Acholi-language radio station, so there was bound to be interest in a follow-up. As a result, Apire returned to the Bishop's office the following day with his brothers, one of whom represented his rwot (the traditional chief of Patiko). Journalists from the Acholi language newspaper and FM radio station were also present. The Bishop allowed a meeting with the woman under his protection, and she declared that Apire was not the one who spoke to her. She said that the first time she had heard his voice was on that day. This seemed to suggest Mr Red was innocent, but the Bishop was still keen to draw him into his orbit. He wanted him to become 'born again' under his auspices. As Labol noted, that actually looked like his best chance of surviving. It was for this reason that Jacky Atingo was asked to attend the service on the following Sunday, when Apire was called up to the altar by the Bishop, together with the converted ajwaka. According to Apire, the Bishop had just said: "This man is not a wrongdoer. He is a human being like the rest of us. He knows God. If you know this man is a wrongdoer, raise your hand". When no one raised their hand, the Bishop put his hand on Charles' head and officially forgave him, saying: "Let us now recognise this in front of God".

Apire then stayed with the Bishop for a while, and benefitted from his protection. However, as we have seen, problems arose again early in 2015. In late February, Apire had been released from prison, following the accusations that he had stabbed people over the Christmas period. I asked my son who was in Gulu at the time to find him with Tonny Labol, and ask about recent events. Apire explained that he was leaving church when he heard a mob, including the members of local councils and the RDC shouting his name. He went to the police station to check if it was him that they were looking for and to ask if he was safe or not. The police said they were, and he was not. They then put him in jail for two weeks against his will, together with rapists, thieves, and murderers. He also has heard that some people have gone to see witchdoctors in South Sudan to curse him: "They hoped to come back to a dead body, but they did not find it!" He was told that some of the witchdoctors carried out the curse, but others refused to do so, because they thought 
he is innocent and that the problem is a clan dispute combined with gossip. Meanwhile, an angry mob lead by local councillors evicted the woman who was renting his property in town. Apire is now hoping the Acholi Paramount chief will assess all that has happened, and will find in his favour. Perhaps rather optimistically, he also still expects the formal legal system to find him innocent of any crimes. At that point he anticipates being able to claim compensation for all his destroyed possessions. Meanwhile, multiple murders remain unsolved, and the circulation of scary ideas about evil acts is unlikely to stop any time soon.

The story of Mr Red illustrates aspects of local justice in post-war northern Uganda that are not hidden, but are persistently overlooked. Indeed, hearing aid agency staff and government officials promoting rule of law or access to justice in northern Uganda, one would have to assume they do not read the local newspapers, go to church services, listen to the radio, or even just look out the window. But of course, most of them do. It is perhaps just the expatriate personnel who are really in the dark. After all, as we have seen, members of the local councils, the mayor, Church leaders, members of parliament, the police and even the President's representative in the district are playing roles in a realm of social accountability that have little to do with national or international judicial norms. Such factors lie behind the prevalence that has been noted in the introduction to this article of popular justice in the form of vigilante acts, as well as efforts to draw formal legal mechanisms and government officials into imposing controls on alleged witches and witchdoctors. The enthusiasm among development agencies for promoting traditional mechanisms threatens to push that process further. Even the Word Bank has hailed such mechanisms as "best-fit" where the prospects of providing more conventional judicial measures are remote, although it wisely adds the proviso that local processes would need to be "pulled in the direction of international norms". ${ }^{29}$ Careful monitoring is essential, and often that does not occur.

In the $\mathrm{Mr}$ Red case, the active involvement of the Anglican Bishop, the MPs, local councils and other government officials is particularly interesting in highlighting ways in which political and social elites openly evoke notions of 
good and evil to define moral communities as a means of asserting their claims as leaders. It is a logic of moral populism, which they openly use for strategic purposes. Alex de Waal has shown how the African elites he has observed compete in what he calls the political marketplace. He argues that there is a financial price for loyalty, and leaders have to pay it, usually in cash. ${ }^{30}$ Other scholars, some focussing specifically on Uganda, have referred to elite bargains, whereby the mass of the population is effectively excluded from political processes. ${ }^{31}$ These arguments are insightful, but tend to beg the question of how such elites connect with wider populations when they require a political constituency. Populist approaches, playing on fears associated with primarily moral threats, are a common answer. This can occur at a national level. In Uganda, President Museveni's government has supported a relatively free media and encouraged newspapers and radio programmes to focus on things like homosexuality, promiscuity, and the most weird and shocking aspects of the LRA. ${ }^{32}$ At the same time, formal political structures have been hollowed out, and the directly elected local council system that has been established institutionalises populist mobilisation. This was an aspect of Uganda's response to the HIV/AIDS pandemic. The local councils promoted, and occasionally enforced, behavioural change, and sometimes the idiom of witchcraft was used to do so. ${ }^{33}$

In the case of Mr Red, the opposition MP interviewed was disarmingly straightforward about it. She explained at length how MPs in the ruling party were given money to hand out at election times, or when the President visited the region. However, M Ps in her party had no such resources. So she had to go directly to the people, and to call on them to mobilise and act in their interests. She openly suggested to them that conventional systems of policing and seeking justice are inadequate. A vigilante response to perceived crimes and experiences of insecurity was essential, and one that regulated the moral

30 A. de Waal, World Peace Foundation, The Political Marketplace: Analyzing Political Entrepreneurs and Political Bargaining with a Business Lens, 17 October 2014, <sites.tufts .edu/reinventingpeace/2014/10/17/the-political-marketplace-analyzing-political -entrepreneurs-and-political-bargaining-with-a-business-lens/>, visited on 11 April 2015.

31 S. Lindemann, 'Exclusionary Elite Bargains and Civil War Onset: The Case of Uganda', 2:76 Crisis States Working Paper (2010); S. King and S. Hickey, 'Beyond Elite Bargains: Building Democracy from Below in Uganda', 45 Effective States and Inclusive Development (2015).

32 T. Allen and N. Stremlau, 'Media Policy, Peace and State Reconstruction' in O. Hemer and T. Tufte (eds.), Media and Global Change: Rethinking Communication for Development (CLACSO/Nordicom, Göteborg, 2005).

33 T. Allen, 'AIDS and Evidence: Interrogating Some Ugandan Myths', 38:1 Journal of Biosocial Science, (2006) pp. 7-28; Allen, supra note 20. 
order. It was therefore acceptable to destroy Mr Red's property and dismiss his rights to purchased land. The resident clan could take his land at Akonyi Bedo back, because Mr Red was not a good man. Interestingly, Apire himself asserted his clams to land and property on the basis of being good and bringing development. He emphasised this rather more than the fact he had paid for them.

The RDC and other government officials reached out to people in a comparable manner, initiating the 'election' of the blood-sucking murderer. Apire was not happy with the result, but was invited to caste a vote himself, and no one interviewed expressed the view that the approach was peculiar or unreasonable, or that it was something that will be avoided in the future. Both the RDC and the DPC supported the setting up of local security committees, and the local councils organised them. The vigilante mobs that attacked Apire's property, and later evicted his tenant and tried to lynch him in the town involved local council office holders. According to Apire, it was hearing well-known local councillors calling his name that made him go to the police station in January 2015, only to be put in jail. He also claims the RDC was actually part of the group. In a revealing interview, the head of the local council who helped organise the removal of the woman who was renting Apire's house, stated that he did not believe that 'Mr Red' was a murderer, or that the woman was his 'wife'. In fact she had a reputation as a good and hardworking woman. He explained that he had to expel her because of the community perception. His role was to act on that basis, irrespective of facts. When asked about involving the police, he just made a dismissive noise, and changed the subject.

The Anglican Bishop seemed disinterested in corroborated facts as well, and was equally willing to engage with the issue as if the rumours about Mr Red were true. His objectives were manifestly more about what he perceived the religious needs of his flock to be, and showing that his church was a place where their fears about witchcraft and negative spiritual forces could be confronted. He took the opportunity to show that his 'born again' conception of Christianity was effective, and to assert his authority in relation to pastors who have reputations for exorcisms and the newer Pentecostal churches that are not part of the Anglican faith. His priority was to have Apire, a devout Catholic, blessed on his altar, rather than securing for him conventional rights or justice. This is reflected in his disinterest in the checking of empirical details - such as how those murdered actually died or whether or not phone calls had actually been made to the converted ajwaka under his protection. For him these matters were incidental to deeper truths, and the need to draw out moral lessons for his congregation. 
Finally, while most aspects of the Mr Red story illustrate long-standing and widespread local responses to imposing social accountability in Uganda and elsewhere, there is something about it that is different. I have worked in this part of Africa since the early 1980s, and have researched numerous instances of witch-cleansing. Almost always those scapegoated have been economically marginal and socially expendable. ${ }^{34}$ Apire is relatively wealthy. It is not surprising that an affluent person is a figure of fear, suspicion and rumour mongering, but vigilante action against such a person on grounds of witchcraft is not common. This is a point that recurs throughout White's book on the history of African vampire rumours in colonial times. ${ }^{35}$ The concerns she records were focussed on the blood-sucking, cannibalistic, resource-accumulating practices of comparatively powerful individuals. Yet those were not the people who were actually attacked. Instead, impoverished people were the targets. So, why was Apire an exception?

The use of the voting mechanism was doubtless important. The election of witches under the auspices of local councils and government officials is something that has been introduced in recent years. As noted, the first instance I came across was in a neighbouring district in $2006 .{ }^{36}$ It was viewed as a progressive and modern response to the problem of witchcraft, was reported on local radio stations and was quickly taken up in other locations, both in Uganda and across the border in South Sudan. For those fearing local practitioners of evil procedures, it has a huge advantage in that no one is specifically associated with an accusation because the voting occurs anonymously. There is, therefore, it is said, less risk of the accused taking revenge. The arrangement allows for a consensus in the population to be articulated with no individual being personally responsible. However, there does seem to have been something else going on in the Mr Red case too.

Apire apparently received an overwhelming number of votes, but there was no public announcement by the officials involved. Instead, an effort was made to keep the results secret. According to some of those interviewed, this revealed that certain important figures were actually trying to protect him, whatever they claimed in public. Possibly this was to avoid being implicated in events. It is rumoured that Apire had been connected with members of the Ugandan security forces, and that he had been in conflict with his handlers over the activities of a rogue unit that had taken to robbery and other criminal acts. There are confused conspiracy stories of an intelligence network, of

34 Allen, supra note 21.

35 White, supra note 2.

$36 \quad$ Allen and Reid, supra note 22. 
prostitution rackets, of pornographic video parlours, and the use of sorcery in campaigns against anti-government activists. I have found no robust evidence about this, but possibly there is something factual somewhere in these accounts, and perhaps, Apire has fallen foul of infighting within parts of the district security apparatus. Maybe that helps explain why he has been foregrounded as a suitable target. He would not be the first relatively prominent person in Uganda whose moral integrity has been challenged for strategic purposes. Nevertheless, the particular mode of making him a pariah remains significant. The focus on him as 'Mr Red', and on evil magic, child sacrifice, blood-sucking and practicing witchcraft resonates with local fears, and allows for the manipulation of panic. It suggests that a logic or moral populism is as appropriate for those managing semi-clandestine security operatives as it is for opposition MPs, the RDC, the mayor, local councillors and the Anglican Bishop. 